\title{
A Word of Caution: Human Rights, Disability, and Implementation of the Post-2015 Sustainable Development Goals
}

\author{
Claire E. Brolan \\ School of Public Health, University of Queensland, Public Health Building, Herston Road, Herston, \\ Brisbane St Lucia 4006, Australia; c.brolan@uq.edu.au; Tel.: +61-733-655-345 \\ Academic Editor: Anna Arstein-Kerslake \\ Received: 30 March 2016; Accepted: 6 May 2016; Published: 14 May 2016
}

\begin{abstract}
On 25 September 2015, the United Nations (UN) General Assembly unanimously voted for the post-2015 UN resolution on the post-2015 Sustainable Development Goal (SDG) agenda. This article argues that although the post-2015 SDG agenda is an advance on its precursor the Millennium Development Goals (MDGs) — especially for progressing the human rights of persons with disabilities in development settings, everywhere-it should nonetheless be approached with caution. This article will identify "three steps forward" for persons with disabilities within the broad content of the post-2015 SDGs, while also highlighting four potential "steps back". It concludes persons with disabilities, disability rights advocates and their supporters must remain vigilant as the post-SDG UN resolution is now operationalised and implemented by UN Member States and their many partners. This is particularly so if the content of the Convention on the Rights of Persons with Disabilities is to be effectively integrated into the post-2015 development policy and planning landscape.
\end{abstract}

Keywords: human rights; disability; sustainable development goals; SDGs; UN resolution; Convention on the Rights of Persons with Disabilities; CRPD

\section{Introduction}

The United Nations (UN) General Assembly's 25 September 2015 resolution, "Transforming our world: the 2030 Agenda for Sustainable Development", is a "plan of action for people, planet and prosperity" ([1], p. 1, preamble). Consisting of a 35-page, 91-paragraph document, this formative resolution sets out the global community's post-2015 Sustainable Development Goal (SDG) action plan for the next 15 years, until the year 2030. Although it contains much of the "unfinished business" of its precursor blueprint for development, the eight Millennium Development Goals (MDGs), which were introduced to the world in UN Secretary-General Kofi Annan's Road map towards the implementation of the UN Millennium Declaration (Road Map report) of September 2001 (Figure 1) [2], the 17 SDGs outlined in the September 2015 resolution undoubtedly advance the MDG agenda (Figure 2). This is primarily because the UN resolution on the post-2015 SDGs shifts the world's development focus from poverty eradication (as emphasised by the MDGs) to poverty eradication and sustainable development, while also reinforcing the inclusive nature of the new goals through its central principle- "that no one will be left behind" ([1], p. 1, preamble). 


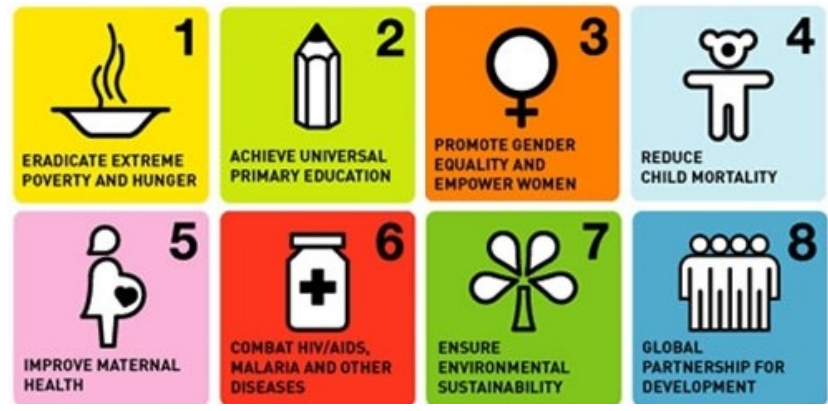

Figure 1. The eight MDGs contained in the UN Secretary-General's Road Map report of September $2001[2]$.

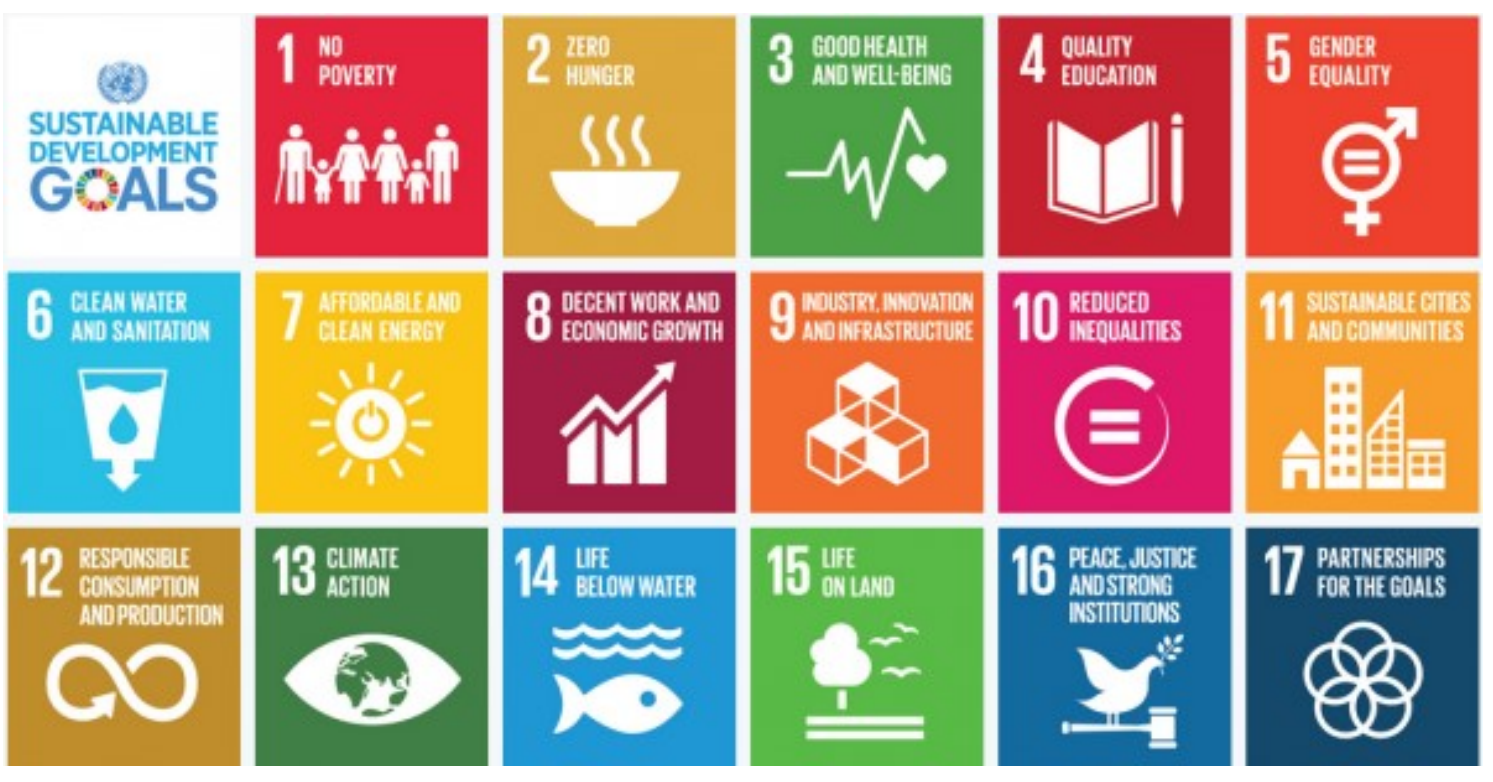

Figure 2. The 17 SDGs outlined in pages 14-27 of the UN resolution on the post-2015 SDG agenda [1].

The question I will seek to address in this article for Laws' Special Issue on Disability and Human Rights, however, is whether the 17 SDGs are as "bold and transformative" ([1], p. 1, preamble), if not adequately sufficient, to provide seminal instruction for the de facto advance of the human rights of persons with disabilities in the unfolding twenty-first century. My views in response to this question are based on having worked as part of a right to health research collaborative for the last three years, tasked with empirically monitoring and providing advice to the European Commission on health's location in the unfolding post-2015 SDGs [3-5]. These views are further grounded in my recent, parallel experience in both disability research and rights advocacy [6-10].

This article will begin by setting the scene through establishing the relationship of the Convention on the Rights of Persons with Disabilities (CRPD) with sustainable development, followed by examining the formulation of the post-2015 SDG agenda. Once this contextual landscape has been outlined, the three key ways in which the SDG framework is an advance on the MDG agenda for persons with disabilities will be highlighted. I will then proceed with trepidation; detailing four reasons why I fear that the cogency of the SDG moment is not all that it seems for advancing not only human rights generally, but more specifically, the human rights of persons with disabilities. I wil conclude by briefly recommending potential advocacy strategies for ensuring the rights of persons with disabilities in the next 15 years are in the post-2015 SDG spotlight. However, this will not be "a doddle". 


\section{Background}

\subsection{The CRPD and Sustainable Development}

Since the eight MDGs were introduced to the world in 2001 in the wake of the Millennium Declaration of September 2000 [2,11], the international human rights legal landscape for persons with disabilities has significantly progressed. This is due to the international community's development and adoption of the CRPD [12], which builds upon the social model of disability and "introduces a new disability rights paradigm" [13]. The CRPD, along with its Optional Protocol, was adopted by the UN General Assembly on 13 December 2006 and entered into force on 3 May 2008 [12]. Within its preamble, the CRPD reiterates the "integral" rights-based relationship between persons with disabilities and the achievement of sustainable development; a relationship that must be mainstreamed ([12], preamble g). The CRPD's preamble further highlights how pursuit of the human rights of persons with disabilities will ultimately assist in overcoming poverty and the varied yet interconnected development challenges facing many millions of persons with disabilities, their families and communities ([12], preamble $\mathrm{m}$ ).

Although it took until the new millennium and some 60 years since the birth of the UN Charter for a UN Convention to be devised to ensure affirmative steps are taken to respect, promote and fulfil the human rights of the "biggest definable disadvantaged group on the planet" ([14], p. 548), one positive burgeoning effect of the CRPD is no less evident-and most welcome-in the international development field. Article 32 of the CRPD (International Cooperation), for example, has been an instructive legal catalyst for high-income countries to devise and advance (and importantly allocate resources toward) disability-inclusive development programs in their foreign affairs and international development portfolios [15]. Therefore, what has traditionally been a neglected area in development policy and planning efforts—disability-inclusive development [16,17] —is now increasingly at the fore and must be lauded.

The growing global focus and promotion of disability-inclusive development, particularly since 2010, is without doubt intimately connected to the CRPD's parallel arrival on the world stage. Indeed, Article 32(1)(a) directs States Parties to ensure, among other measures, "that international cooperation, including international development programmes, is inclusive of and accessible to persons with disabilities" [emphasis added] [12]. Although Article 32 sets out all nation's extra-territorial obligations to support "the importance of international cooperation and its promotion, in support of national efforts for the realization of the purpose and objectives of the present Convention" [13], the primary onus is on State Parties to take the necessary measures to realise the CRPD's provisions in both de jure law and de facto reality inside their sovereign borders. Again, Article 32(2) makes this clear: "The provisions of this article are without prejudice to the obligations of each State Party to fulfil its obligations under the present Convention" [12].

It is estimated approximately $80 \%$ of the world's more than one billion persons with disabilities reside in a developing country context, frequently in poverty [1,18]. Accordingly, "Disability is a development issue, because of its bidirectional link to poverty: disability may increase the risk of poverty, and poverty may increase the risk of disability" ([19], p. 10). Subsequently, today there is great onus on low- and middle-income countries to step up and work hard to overcome the extraordinary legal, policy, social, structural, environmental, socio-cultural and other entrenched barriers (including those related to the human right to health and health's underlying social determinants) for persons with disabilities [18,19]. In turn, and pursuant to Article 32, high-income nations and their partners must also rise to support countries with lessor resources, technical capacity, and knowledge to implement the Convention's terms. It is of little wonder, therefore, that disability advocates are now asking whether or how the SDGs of September 2015 and Article 32 intersect.

\subsection{A Closer Look at the Formulation of the Post-2015 SDG Agenda}

Similar to the CRPD, the post-2015 SDG agenda emanates from a UN resolution that enjoys unanimous government support [1]. The September 2015 resolution is the output of a formidable global 
consultation process involving Member States, the UN, civil society, non-government organisations (NGOs), academic agencies, and a host of other actors and advocates. From the UN Conference on Sustainable Development (Rio+20 Conference) in Brazil in June 2012 to UN Director-General Ban Ki-moon's July 2012 appointment of a High-Level Panel of Eminent Persons on the Post-2015 Development Agenda (High-Level Panel), vigorous dialogue continued over the framing of the MDG's successors. The UN Development Group (UNDG) also took steps to realise the UN's aim to incorporate as many voices into a global post-2015 dialogue, including voices that may otherwise not be heard [20]. An ambitious post-2015 consultative strategy was thus embarked on. This involved the UNDG supporting at least 100 national-level dialogues, convening 11 global thematic consultations (in conjunction with its governmental partners), and creating an interactive web portal to stimulate citizen and stakeholder engagement [20].

The global thematic consultation process occurred between May 2012 and June 2013, and divided post-2015 discussion priorities into 11 thematic branches (Table 1) [21]. While disability was not a thematic topic in and of its own right, persons with disabilities and international disability advocacy agencies, and their supporters, certainly contributed to the dialogue within each thematic branch, as well as ensuing discussion in UN, country, and other forums. Within these forums, there was strong promotion by disability advocates, such as the International Disability Alliance and International Disability and Development Consortium, for the new SDG framework to be expressly underpinned by human rights [22]. The importance given to including the rights of persons with disabilities in the formulation of the post-2015 goals culminated in a High-Level Meeting on Disability and Development on 23 September 2013 at the UN headquarters in New York [23]. The overarching theme of this meeting, "The way forward: a disability inclusive development agenda towards 2015 and beyond", was attended by heads of state and government and resulted in an action-oriented outcome document in support of the aims of the CRPD and the realisation of the MDGs [23,24].

Table 1. Focus of the 11 global thematic consultations.

\begin{tabular}{cc}
\hline Thematic Consultation Number & Issue Focus \\
\hline 1 & Conflict, Violence and Disaster \\
2 & Water \\
3 & Education \\
4 & Energy \\
5 & Environmental Sustainability \\
6 & Food Security and Nutrition \\
7 & Governance \\
8 & Growth and Employment \\
9 & Health \\
10 & Addressing Inequalities \\
11 & Population Dynamics \\
\hline
\end{tabular}

When the SDG document was adopted by UN Member States on 25 September 2015, the profile of-and need to prioritise-persons with disabilities within the new post-2015 development agenda was arguably high. This sharply contrasted with the wholesale lack of participation and focus on the development needs of the world's persons with disabilities in the MDG formulation process 14 years earlier [25]. In contrast, the MDGs were devised in a cloistered "top down" manner by a select cluster of high-level UN technocrats (and their associates) in the spring and summer of 2001 [26-29]. Although the content of the eight MDGs was allegedly based on the broadly worded goals of the Millennium Declaration that UN Member States had already collectively agreed to and signed in September 2000 [27,30], the MDGs release in the annexure of UN Secretary-General Kofi Annan's Road Map report a year later raised concern. The new United States government, led by President George W. Bush, especially queried the MDGs' legitimacy in light of the eight goals not being officially developed nor formally endorsed by the Member States at the UN General Assembly [31]. 
Human rights were a victim of this closed, high-level negotiation and decision-making process [28]. When reflecting on the MDGs' construction, co-chair of the UN inter-agency expert group responsible for the MDGs, Jan Vandemoortele, is unequivocal in terms of human rights' marginalisation from MDG decision-making:

"[The MDGs] express targets that are feasible at the global level. They should not been seen as a normative statement of what is desirable in an ideal world, which is already embedded in the various human rights treaties that have been ratified by member state to varying degrees. There is no need to repeat or overlap with these instruments ... " ([32], p. 14).

David Hulme, a second-hand informant who has written extensively on the MDGs formulation, reinforces the eight MDGs and their associated targets were configured in 2001 to avoid "potentially difficult-to-measure goals like human rights and participation" [33]. Hulme explains MDG architects were amenable to placing such concepts in the introductions and conclusions of the key documents "but not in the lists that were to guide plans of action" [33].

Although human rights were not expressly incorporated in the MDG list, they were repeatedly referred to in the UN Secretary-General's Road Map report, to which the MDGs were annexed. Moreover, the Millennium Declaration, which facilitated the release of UN Secretary-General Kofi Annan's Road Map report, was explicitly grounded in a vision for development that advanced human rights [34]. However this vision for development did not affirmatively identify persons with disabilities and constructive advancement of their rights [25].

As established, the CRPD was negotiated after the MDG's release. The positive participation of persons with disabilities in the CRPD's development between 2002 and 2006 reflected the international disability movement's long-standing mantra, "Nothing About Us Without Us" [35]. The successful, speedy formulation of this UN Convention clearly demonstrated to the UN and its Member States how the formulation of future human rights treaties, and future formulation of high-level policy and planning frameworks such as the post-2015 development goals, must be done. That is, inclusively; with the people at the heart of the document participating in formal UN deliberations. Of course, while it is unknown how much the voices (and whose voices) elicited through the vast post-2015 consultation process actually influenced the final SDG text in September 2015, the effort and resource invested in attempting to engage voices from the global community in the SDG's formulation is progress on the nature of the MDG's birth.

\section{The Post-2015 SDGs Are an Advance on the MDG Agenda for Persons with Disabilities}

Following the secretive manner in which the MDGs were born, the MDG framework became interpreted and applied by the UN, its Member States and development partners as a development agenda applicable to "the Other" residing in poor countries [36]. While the enormous positive, life-changing benefits that have flowed for millions of highly marginalised people and disadvantaged communities as a result of the eight MDGs should not be decried [37], there were two obvious deficits with the MDG framework that the post-2015 SDG agenda seeks to remedy (among others). These two factors are connected to, and pertinent for, advancing the human rights of persons with disabilities around the world. Firstly, the SDGs are a universal agenda and apply to everyone, everywhere; and secondly, the SDGs expressly include persons with disabilities.

\subsection{The SDGs Are a Universal Agenda}

In light of the basic principle of the post-2015 SDGs "that no one will be left behind", the SDGs contain a "new universal Agenda": they are applicable to all, everywhere, in low-, middle- and high-income countries alike ([1], p. 1, preamble). Paragraphs 4 and 5 of the UN Resolution of September 2015 are most eloquent in establishing the SDG's universal character: 
"As we embark on this great collective journey, we pledge that no one will be left behind. Recognising that the dignity of the human person is fundamental, we wish to see the Goals and targets met for all nations and peoples and for all segments of society. And we will endeavour to reach the furthest behind first" ([1], para. 4).

"This is an Agenda of unprecedented scope and significance. It is accepted by all countries and is applicable to all, taking into account different national realities, capacities and levels of development and respecting national policies and priorities. These are universal goals and targets which involve the entire world, developed and developing countries alike. They are integrated and indivisible and balance the three dimensions of sustainable development" ([1], para. 5).

Iteration within the resolution that its contents are applicable to all, everywhere, ensures the SDGs clearly depart from the MDGs: the SDGs are to be applied to all rather than occidentally applied to "the other" in "those" lower income nations. While the world must not divert its attention from the plight of persons living in utterly desperate circumstances in low-income nations and fragile and conflict-affected states in pursuing the post-2015 SDG agenda [38,39], today the bulk of people living in poverty reside in middle-income countries [40]. Furthermore, in ensuring "that no one will be left behind" ([1], p. 1, preamble), the SDGs recognise the importance of redressing inequities experienced by vulnerable and marginalised groups and communities (including persons with disabilities) in high-income nations. Even though such persons do reside in high-income countries, their experience of relative poverty, disenfranchisement and disadvantage remains unjust, and their governments need to be held accountable and accordingly improve domestic policy and law in line with their SDG commitments [41].

\subsection{The SDGs Explicitly Embrace a Human Rights Agenda}

The UN General Assembly's September 2015 resolution reiterates the association between human rights and the post-2015 SDG agenda:

"[The 17 SDGs and 169 targets are a] ... new universal Agenda. They seek to build on the MDGs and complete what they did not achieve. They seek to realise the human rights of all ... " ([emphasis added] ([1], p. 1, preamble)).

The Declaration envisages a world "of universal respect for human rights and human dignity, the rule of law, justice, equality and non-discrimination" ([1], para. 8), noting the new SDG agenda is:

"Guided by the purposes and principles of the Charter of the UN, including full respect for international law. It is grounded in the Universal Declaration of Human Rights, international human rights treaties, the Millennium Declaration and the 2005 World Summit Outcome. It is informed by other instruments such as the Declaration of the Right to Development" ([emphasis added] ([1], para. 10)).

Within paragraph 19, the Declaration again reinforces human rights' centrality to the SDG's achievement, which expressly includes the "human rights and fundamental freedoms" of persons with disabilities:

"We reaffirm the importance of the Universal Declaration of Human Rights, as well as other international instruments relating to human rights and international law. We emphasize the responsibilities of all States, in conformity with the Charter of the UNs, to respect, protect and promote human rights and fundamental freedoms for all, without distinction of any kind as to race, colour, sex, language, religion, political or other opinion, national or social origin, property, birth, disability or other status" ([emphasis added] ([1], para. 19)). 
Through the content of the resolution's preamble, and paragraphs 8, 10, 19 and 20, the following observations about human rights' intersection in the post-2015 SDG agenda can be made. First, not only are human rights prominent in the SDG agenda, they are integral to its realisation: the post-2015 agenda is a human rights agenda explicitly grounded in international law, and more specifically, the laws espoused in international human rights treaties. According to the resolution, sustainable development cannot and will not occur if human rights for all as established in international law, and especially the human rights of women and girls ("half of humanity") are not respected, protected and promoted ([1], para. 20). Therefore, human rights permeate, and are fundamental to, the post-2015 outcome document; international human rights law underpins the post-2015 policy agreed to by UN Member States.

It is also important to illuminate that unlike the Millennium Declaration of 2000, the UN resolution on the post-2015 SDG agenda contains the 17 SDGs. Inclusion of the goals, associated targets and means of implementation within the SDG text juxtapose the eight MDGs release a year after the Millennium Declaration in the annexure of a UN Secretary-General's report. Hence there can be no quibble among UN Member States as to the authority of the 17 SDGs, nor the human rights agenda that underpins them. Together, the latter is visible in the one UN document that the UN General Assembly cumulatively voted on after several years of post-2015 discussion and negotiation.

The UN resolution on the post-2015 SDG agenda also incrementally builds on the CRPD's reconciliation of the rights contained within the International Covenant on Political and Civil Rights and the International Covenant on Economic, Social and Cultural Rights of 1966 ([35], p. 10). The UN resolution of September 2015 repeatedly uses the phrase "integrated and indivisible" to describe both the interlinkage of all 17 SDGs and 169 associated targets, and the 17 SDG's subsequent interconnection with the remaining content of the UN resolution on the post-2015 agenda ([1], p. 1, preamble 5, 18, 55, 71). For example, the UN General Assembly states: "We [the UN General Assembly] reiterate that this Agenda and SDGs and targets, including the means of implementation, are universal, indivisible and interlinked" [emphasis added] ([1], para. 71). Use of the words "universal" and "indivisible" echo the Vienna Declaration and Programme of Action of 1993's historic affirmation "all human rights are universal, indivisible and interdependent and interrelated" ([42], para. 5), which the CRPD (the first international convention to be drafted following the Vienna Declaration of 1993) embraced ([35], p. 10).

Use of these terms by the UN General Assembly in September 2015 is not accidental: it is a nod to the Vienna Declaration of 1993 and the holistic nature of human rights (as interlinked and indivisible). Yet, and perhaps most significantly, paragraph 71 implicitly attaches human rights to the SDG metrics framework ([1], pp. 14-27). This significantly differs to the MDG list, wherein the UN technocratic decision-makers purposively sidelined human rights from the Millennium Declaration's plan of action: the eight MDGs released one year after the Millennium Declaration. Now, the post-2015 metrics framework is embedded in, and an expression of, political, civil, economic, social and cultural rights and their realisation. In other words, the 17 SDGs have metamorphosed into the new human rights and development post-2015 road map, which is not annexed to a UN Secretary-General report, but incorporated in the UN resolution adopted by the UN General Assembly in September 2015.

\subsection{The SDGs Expressly Include Persons with Disabilities}

Not only are persons with disabilities implicitly included in the SDGs through its universal agenda, they are explicitly identified:

"People who are vulnerable must be empowered. Those whose needs are reflected in the Agenda include all children, youth, persons with disabilities (of whom more than 80 per cent live in poverty), people living with HIV / AIDS, older persons, indigenous peoples, refugees and internally displaced persons and migrants" ([emphasis added] ([1], para. 23)).

It follows that persons with disabilities are expressly referred to in four locations in the 17 goals and their 169 associated targets and means of implementation. Persons with disabilities are identified 
with respect to the achievement of three SDGs: Goal 4 (Quality education), Goal 8 (Decent work and economic growth) and Goal 11 (Sustainable cities and communities) (Table 2). In light of persons with disabilities omission from the eight MDGs and their associated targets annexed to the UN-Secretary General's Road Map report in 2001 [2], the specific inclusion of persons with disabilities in both the terms of the UN Declaration and the content of its 17 SDGs could be interpreted as a major win. Certainly, and as Mercer and MacDonald point out, it is "astonishing" that the MDGs excluded persons with disabilities, especially when many of the MDGs (if not all) "cannot be met without addressing disability issues in the developing world" ([14], p. 549).

Table 2. Inclusion of Persons with disabilities in the SDG metrics framework ([1], pp. 14-27).

\begin{tabular}{lll}
\hline \multicolumn{1}{c}{ SDG } & \multicolumn{1}{c}{ Metric } & \multicolumn{1}{c}{ Target Aim } \\
\hline $\begin{array}{l}\text { Goal 4: } \\
\text { Quality Education }\end{array}$ & Goal 4, Target 5 & $\begin{array}{l}\text { 4.5 By 2030, eliminate gender disparities in education and } \\
\text { ensure equal access to all levels of education and vocational } \\
\text { training for the vulnerable, including persons with disabilities, } \\
\text { indigenous peoples and children in vulnerable situations }\end{array}$ \\
\hline $\begin{array}{l}\text { Goal 8: } \\
\begin{array}{l}\text { Decent work and } \\
\text { economic growth }\end{array}\end{array}$ & Goal 8, Target 5 & $\begin{array}{l}\text { 8.5 By 2030, achieve full and productive employment and decent } \\
\text { work for all women and men, including for young people and } \\
\text { persons with disabilities, and equal pay for work of equal value }\end{array}$ \\
\hline $\begin{array}{l}\text { Goal 11: } \\
\begin{array}{l}\text { Sustainable Cities } \\
\text { and Communities }\end{array}\end{array}$ & Goal 11, Target 2 & $\begin{array}{l}\text { 11.2 By 2030, provide access to safe, affordable, accessible and } \\
\text { sustainable transport systems for all, improving road safety, } \\
\text { notably by expanding public transport, with special attention to } \\
\text { the needs of those in vulnerable situations, women, children, } \\
\text { persons with disabilities and older persons }\end{array}$ \\
\hline $\begin{array}{l}\text { Goal 11: } \\
\text { Sustainable Cities } \\
\text { and Communities }\end{array}$ & Goal 11, Target 7 & $\begin{array}{l}\text { By 2030, provide universal access to safe, inclusive and } \\
\text { accessible, green and public spaces, in particular for women and } \\
\text { children, older persons and persons with disabilities }\end{array}$ \\
\hline
\end{tabular}

\section{Three Steps Forward, But Four Steps Back}

The UN resolution on the post-2015 SDG agenda is a remarkable achievement-its contents definitively highlight and advance the rights of persons with disabilities in development contexts worldwide. This is especially so when compared to the vacuous hole in the MDG list regarding human rights and persons with disabilities, as well as in the MDG's antecedent the Millennium Declaration, which excluded persons with disabilities. Nonetheless, this article identifies four reasons why the post-2015 SDG agenda, as a human rights agenda and a human rights agenda for persons with disabilities, is to be cautiously approached. These four reasons include: the lack of binding status in international law for the UN resolution on the post-2015 SDG agenda; its weak governance and accountability mechanisms; the SDG metrics framework's (that is, the 17 SDGs and their 169 associated targets and means of implementation) sidelining of human rights; and finally, the SDG metrics framework's insufficient identification and inclusion of persons with disabilities.

\subsection{The UN Resolution on the Post-2015 SDGs Is a High-Level Policy Document Only, It Is Not Binding Instrument of International Law}

This article has established that the UN resolution on the post-2015 SDGs references, and is grounded in, the body that is international human rights law ([1], p. 1, preamble, para. 3, 8, 10, 19-20, 29, 35). And, this body of international human rights law (in its various iterations) has been widely adopted by the international community of UN Member States. However, the UN resolution on the post-2015 SDG agenda is not a UN treaty document or binding international human rights law instrument per se, which means it is not governed by international law. Rather, it is a piece of soft law: it is an expression of agreed-upon international goals and aspirations, despite espousing some norms of customary international law. 
The lack of "hard law" status for the UN resolution on the post-2015 SDG agenda is problematic for several reasons. Even though there was widespread government endorsement (and vote) for the SDGs in September 2015, countries are not legally obliged to implement or realise within their domestic jurisdictions the terms of this human rights document, or the content or human rights framing of its 17 SDGs. As a piece of soft law, the provisions of the Vienna Convention on the Law of Treaties 1969 do not apply [43]. This includes the Pacta Sunt Servanda rule encapsulated in Article 26: Every treaty in force is binding upon the parties to it and must be performed by them in good faith ([43], Article 26).

Alternatively, others might argue that if the UN resolution on the post-2015 SDG agenda cannot be interpreted as a matter of international statutory law, then it should be construed as customary international law per Article 38(1)(b) of the Statute of International Court of Justice (ICJ) [44]. Supporters of this argument might point to the UN resolution on the post-2015 SDG agenda's international human rights law underpinning, and its ensuing containment of a cluster of customary international law rules. Yet successfully characterising the UN resolution on the post-2015 SDGs as a piece of customary international law pursuant Article 38(1)(b) is unlikely. This is because the ICJ is cautious in ascertaining the existence of customary international laws [45], and in its reticence has settled on two components necessary for the constitution of custom per Article 381(1)(b); the state practice (or the material fact) and the opinio juris; a subjective or psychological element that is related to the consent (or belief) of the State that such behaviour is "law" ([46], para. 10; [47], p. 58). The argument that either of these two components exists for this UN resolution to constitute customary international law is wanting.

Firstly, the state practice component is weak. Turning to the historical, it was UN Member State practice to treat the MDGs, the SDG's predecessor, as a non-binding policy commitment only. Also, the opinio juris component is equally feeble. This is because analysis of the high-level contemporary discourse on the formulation of the SDGs reveals it was never the collective intention of the UN General Assembly's Member States to create a piece of binding international law (especially human rights law) when engaging in the formulation of the text of the UN resolution on the post-2015 SDGs or in the formulation of its list of 17 goals therein [48]. Had this been otherwise, decision-making consensus between UN Member States would have been extremely difficult to reach at the UN in New York in September 2015 [48].

\subsection{As a High-Level Policy Document without Legal Standing, Its Accountability Mechanisms Are Flimsy}

The next reason the UN resolution on the post-2015 SDG's lack of standing in international law is problematic for the SDG's de facto achievement is because without such legal standing, the resolution cannot establish an authoritative international implementing body or accountability mechanism akin, for example, to the overseeing committees of the UN treaty documents. While the power and influence of these overseeing bodies has been criticised, at least there is an overarching implementation mechanism for the monitoring of UN treaty implementation, grounded in international law (however imperfect), in existence. The fact this is not the case for the ambitious post-2015 SDG action plan-a "plan of action for people, planet and prosperity" ([1], p. 1, preamble)—is a major deficit. ${ }^{1}$

Following on, "SDG 17: Strengthen the means of implementation and revitalize the Global Partnership for Sustainable Development" and its 19 targets ([1], pp. 26-27) appear to be an expanded yet recycled version of "MDG 8: Global Partnership for Development" and its six targets (Tables 3 and 4) [50]. As has been well-documented, government support for MDG 8 waned as the MDG agenda progressed in the mid-to-late 2000s, particularly in the wake of the Global Financial Crisis of 2008 [37,50], and

1 I note that subsequent to writing this article, and such is the dynamic nature of the entire SDG process, a High-Level Political Forum on Sustainable Development (the "HLPF") has been advertised by the UN as the planned "central platform for the follow-up and review of the 2030 Agenda for Sustainable Development and the SDGs" [49]. As to whether the HLPF will be duly respected by the UN Member States (and their development partners), and duly funded, so as to become an effective overarching accountability mechanism remains to be seen. 
government's viewed MDG 8 as a "weak goal" [51]. Compounding matters, MDG 8's targets and indicators were reported as being "indifferent to human rights principles", and perversely creating "dynamics and incentives for policy-making that were ultimately detrimental to the implementation of norms on international cooperation for the achievement of human rights" ([52], p. 276; [53]). Consequently, Member States treatment of MDG 8 combined with MDG 8's distilled content (i.e., its emphasis on sweeping general statements as opposed to quantitative, time bound benchmarks: [53]), is a worrying precedent that the content of SDG 17 appears not to have adequately responded to.

Table 3. SDG 17: Strengthen the means of implementation and revitalize the Global Partnership for Sustainable Development.

\begin{tabular}{|c|c|}
\hline Finance & SDG-Target Detail \\
\hline 17.1 & $\begin{array}{l}\text { Strengthen domestic resource mobilization, including through international support to developing countries, to } \\
\text { improve domestic capacity for tax and other revenue collection }\end{array}$ \\
\hline 17.2 & $\begin{array}{l}\text { Developed countries to implement fully their official development assistance commitments, including the } \\
\text { commitment by many developed countries to achieve the target of } 0.7 \text { per cent of gross national income for official } \\
\text { development assistance (ODA/GNI) to developing countries and } 0.15 \text { to } 0.20 \text { per cent of ODA/GNI to least } \\
\text { developed countries; ODA providers are encouraged to consider setting a target to provide at least } 0.20 \text { per cent of } \\
\text { ODA/GNI to least developed countries }\end{array}$ \\
\hline 17.3 & Mobilize additional financial resources for developing countries from multiple sources \\
\hline 17.4 & $\begin{array}{l}\text { Assist developing countries in attaining long-term debt sustainability through coordinated policies aimed at } \\
\text { fostering debt financing, debt relief and debt restructuring, as appropriate, and address the external debt of highly } \\
\text { indebted poor countries to reduce debt distress }\end{array}$ \\
\hline 17.5 & Adopt and implement investment promotion regimes for least developed countries \\
\hline \multicolumn{2}{|l|}{ Technology } \\
\hline 17.6 & $\begin{array}{l}\text { Enhance North-South, South-South and triangular regional and international cooperation on and access to science, } \\
\text { technology and innovation and enhance knowledge sharing on mutually agreed terms, including through } \\
\text { improved coordination among existing mechanisms, in particular at the United Nations level, and through a global } \\
\text { technology facilitation mechanism }\end{array}$ \\
\hline 17.7 & $\begin{array}{l}\text { Promote the development, transfer, dissemination and diffusion of environmentally sound technologies to } \\
\text { developing countries on favourable terms, including on concessional and preferential terms, as mutually agreed. }\end{array}$ \\
\hline 17.8 & $\begin{array}{l}\text { 17.8 Fully operationalize the technology bank and science, technology and innovation capacity-building } \\
\text { mechanism for least developed countries by } 2017 \text { and enhance the use of enabling technology, in particular } \\
\text { information and communications technology }\end{array}$ \\
\hline \multicolumn{2}{|l|}{ Capacity-Building } \\
\hline 17.9 & $\begin{array}{l}\text { Enhance international support for implementing effective and targeted capacity-building in developing countries } \\
\text { to support national plans to implement all the Sustainable Development Goals, including through North-South, } \\
\text { South-South and triangular cooperation }\end{array}$ \\
\hline \multicolumn{2}{|l|}{ Trade } \\
\hline 17.10 & $\begin{array}{l}\text { Promote a universal, rules-based, open, non-discriminatory and equitable multilateral trading system under the } \\
\text { World Trade Organization, including through the conclusion of negotiations under its Doha Development Agenda }\end{array}$ \\
\hline 17.11 & $\begin{array}{l}\text { Significantly increase the exports of developing countries, in particular with a view to doubling the least developed } \\
\text { countries' share of global exports by } 2020\end{array}$ \\
\hline 17.12 & $\begin{array}{l}\text { Realize timely implementation of duty-free and quota-free market access on a lasting basis for all least developed } \\
\text { countries, consistent with World Trade Organization decisions, including by ensuring that preferential rules of } \\
\text { origin applicable to imports from least developed countries are transparent and simple, and contribute to } \\
\text { facilitating market access }\end{array}$ \\
\hline Systemic Issues & Policy and institutional coherence \\
\hline 17.13 & Enhance global macroeconomic stability, including through policy coordination and policy coherence \\
\hline 17.14 & Enhance policy coherence for sustainable development \\
\hline \multirow[t]{2}{*}{17.15} & $\begin{array}{l}\text { Respect each country's policy space and leadership to establish and implement policies for poverty eradication and } \\
\text { sustainable development }\end{array}$ \\
\hline & Multi-stakeholder partnerships \\
\hline 17.16 & $\begin{array}{l}\text { Enhance the Global Partnership for Sustainable Development, complemented by multi-stakeholder partnerships } \\
\text { that mobilize and share knowledge, expertise, technology and financial resources, to support the achievement of } \\
\text { the Sustainable Development Goals in all countries, in particular developing countries }\end{array}$ \\
\hline \multirow[t]{2}{*}{17.17} & $\begin{array}{l}\text { Encourage and promote effective public, public-private and civil society partnerships, building on the experience } \\
\text { and resourcing strategies of partnerships }\end{array}$ \\
\hline & Data, monitoring and accountability \\
\hline 17.18 & $\begin{array}{l}\text { By 2020, enhance capacity-building support to developing countries, including for least developed countries and } \\
\text { small island developing States, to increase significantly the availability of high-quality, timely and reliable data } \\
\text { disaggregated by income, gender, age, race, ethnicity, migratory status, disability, geographic location and other } \\
\text { characteristics relevant in national contexts }\end{array}$ \\
\hline 17.19 & $\begin{array}{l}\text { By 2030, build on existing initiatives to develop measurements of progress on sustainable development that } \\
\text { complement gross domestic product, and support statistical capacity-building in developing countries }\end{array}$ \\
\hline
\end{tabular}


Table 4. MDG 8: Develop a global partnership for development.

\begin{tabular}{ll}
\hline 8.A & $\begin{array}{l}\text { Develop further an open, rule-based, predictable, non-discriminatory trading and financial system } \\
\text { Includes a commitment to good governance, development and poverty reduction-both nationally } \\
\text { and internationally }\end{array}$ \\
\hline 8.B $\quad \begin{array}{l}\text { Address the special needs of the least developed countries Includes tariff and quota free access for the } \\
\text { least developed countries' exports; enhanced programme of debt relief for heavily indebted poor } \\
\text { countries (HIPC) and cancellation of official bilateral debt; and more generous ODA for countries } \\
\text { committed to poverty reduction }\end{array}$ \\
\hline 8.C $\quad \begin{array}{l}\text { Address the special needs of landlocked developing countries and small island developing States } \\
\text { (through the Programme of Action for the Sustainable Development of Small Island Developing States } \\
\text { and the outcome of the twenty-second special session of the General Assembly) }\end{array}$ \\
\hline 8.D $\quad \begin{array}{l}\text { Deal comprehensively with the debt problems of developing countries through national and } \\
\text { international measures in order to make debt sustainable in the long term }\end{array}$ \\
\hline 8.E $\quad \begin{array}{l}\text { In cooperation with pharmaceutical companies, provide access to affordable essential drugs in } \\
\text { developing countries }\end{array}$ \\
\hline 8.F $\quad \begin{array}{l}\text { In cooperation with the private sector, make available the benefits of new technologies, especially } \\
\text { information and communications }\end{array}$ \\
\hline
\end{tabular}

In fact, whilst continuing to apply this dose of political realism, the likely obsequious treatment by UN Member States toward SDG 17 is only reinforced by way of the noncommittal (if not evasive) configuration of Target 17.15. This target advises UN Member States to (rather weakly) "Respect each country's policy space and leadership to establish and implement policies for poverty eradication and sustainable development" [emphasis added] ([1], p. 27). Thus, the governance and accountability mechanisms for the SDG's implementation are not only appearing increasingly weak - they are crumbling. Indeed, it is arguable the UN General Assembly's aspirational aim for MDG's 8 "resuscitated" Global Partnership for Development is undermined from the outset ([1], para. 60).

4.3. What Matters Is What Governments Will Prioritise for SDG Implementation: The 17 Goals, Their Targets and Means of Implementation, and Inter-Linked Country Indicators

What might a non-binding high-level policy document with questionable governance mechanisms practically offer persons with disabilities so as to substantively progress their human rights and sustainable development needs in the post-2015 context? In response, disability advocates might (rightly) cite the UN resolution on the post-2015 SDG agenda's gains over the MDG agenda. That is, the post-2015 SDG agenda embodies a (i) universal (ii) human rights agenda (grounded in international human rights law) that (iii) expressly includes persons with disabilities. Certainly on paper these gains are monumental. However, this "bold and transformative" ([1], p. 1, preamble) post-2015 vision for development might be a mirage not only for persons with disabilities, but for meeting the human rights and development needs of other potentially vulnerable groups identified in the post-2015 UN document (i.e., children, youth, people living with HIV / AIDS, older persons, indigenous persons, refugees and internally displaced persons and migrants ([1], para. 23). Such cause for concern is again grounded in the historical, or on UN Member State's behaviour in interpreting their MDG commitments.

The MDG list of September 2001 did not explicitly contain a human rights agenda. Thus as the new millennium unfolded, a handful of scholars argued that a far greater overlap between human rights and development was needed [52-54]. As mentioned however, the multilateral interagency technocrats who constructed the MDGs in 2001 had no intention of expressly intersecting human rights law with the MDG action plan. Nor did governments, in turn, collectively interpret the eight MDGs through a human rights lens. If anything, the release of the MDG's by way of annexure to the UN Secretary General's Road Map report in 2001 ensured this schism existed between the eight MDGs and human rights located in the MDG's formative document, the Millennium Declaration. Unsurprisingly, in terms of MDG implementation, government at all levels (national, regional, international) focused on 
achieving the MDG metrics framework, or the eight goals and their associated targets and indicators, in a somewhat vertical or reductionist fashion. And, as the MDG decision-makers had ensured, there was a purposive human rights dearth in this framework.

If over ten years of MDG implementation is the litmus test, then it is unlikely the SDGs will be implemented by UN Member States and their partners with human rights foregrounding their SDG investment efforts. This is in spite of the fact the UN resolution on the post-2015 SDG agenda's preamble, the content of its declaration, as well as its 17 SDGs are clearly grounded in international human rights law. Conversely, following MDG experience, it is likely government focus on the SDGs will narrow to solely fixate on implementation of the SDG metrics framework; on achieving the 17 goals, their associated targets and means of implementation, and country-specific indicators. This aligns with the potent adage in international development circles- "what gets measured gets done".

If the SDG metrics will be the UN Member State's (and their partners) main focus, then this is concerning for human rights and disability rights advocates alike. This is because the treatment of human rights within this one UN document is not consistent. For instance on the one hand, human rights principles and international human rights law are privileged within the text of the preamble and larger declaration. Yet, on the other hand, the SDG metrics (found within the same document [1], pp. 14-27) scarcely mention human rights. In fact, "human rights" are referred to only once in the SDG metrics framework, while none of the 17 headline goals explicitly refer to "human rights".

Indeed, close examination of the 17 SDG's 169 targets and means of implementation serves to only reinforce human rights' marginal presence in the SDG metrics. Human rights' shortened version-"rights"-is explicitly found in six locations in the SDG metrics framework: in four targets and two means of implementation (Table 5). This ensures "rights" are expressed in only five of the 17 goals, or less than a third of the SDGs. Further, where "rights" are referred to as "human rights" in the one standalone-but inadequate—target, Target 4.7 (see Table 5), this phrase is inserted to affirm that the learning of human rights in educational settings is to be promoted in educational settings. Of course, the learning of human rights (and greater generation of human rights awareness) is important, but this insertion of human rights within the education goal does not go far enough. Instead, if the SDGs truly embodied a human rights agenda, then SDG 4 and its targets should be explicitly promoting the attainment of education as a matter of human rights for everyone, or express achievement of the human right to education as underscoring the post-2015 education goal [55].

Disparate meaning can also be attached to the framing of "rights" in the SDG metrics. For example, in Target 1.4 and Means of Implementation 5.a, rights are identified as "equal rights to economic resources" (i.e., economic rights). On the other hand, Target 8.8 refers to rights in the context of the protection of "labour rights" (i.e., employment rights). Whereas in Means of Implementation 3.b, rights are now being used to affirm country rights (i.e., "the right of developing countries"). In each instance, the use of "rights" language lacks consistency, and is hardly contentious. Conversely, the lack of rights language to frame numerous targets, embedded in human rights, is particularly instructive. For example, the content of "Target 10.2: By 2030, empower and promote the social, economic and political inclusion of all, irrespective of age, sex, disability, race, ethnicity, origin, religion or economic or other status" and "Target 10.3: Ensure equal opportunity and reduce inequalities of outcome, including by eliminating discriminatory laws, policies and practices and promoting appropriate legislation, policies and action in this regard", are not presented as a matter of fundamental human rights already entrenched in international human rights law. 
Table 5. Rights in the post-2015 SDG framework.

\begin{tabular}{|c|c|c|}
\hline Post-2015 Goal & Target & Means of Implementation \\
\hline $\begin{array}{l}\text { Goal 5: } \\
\text { Achieve gender equality } \\
\text { and empower all women } \\
\text { and girls }\end{array}$ & $\begin{array}{l}\text { 5.6: Ensure universal access to sexual and } \\
\text { reproductive health and reproductive rights as agreed } \\
\text { in accordance with the Programme of Action of } \\
\text { the International Conference on Population and } \\
\text { Development and the Beijing Platform for Action } \\
\text { and the outcome documents of their } \\
\text { review conferences. }\end{array}$ & $\begin{array}{l}\text { 5.a: Undertake reforms to give women equal rights to } \\
\text { economic resources, as well as access to ownership and control } \\
\text { over land and other forms of property, financial services, } \\
\text { inheritance and natural resources, in accordance with } \\
\text { national laws. }\end{array}$ \\
\hline
\end{tabular}

\subsection{The SDG Metrics Framework Does Not Sufficiently Identify and Include Persons with Disabilities}

If the UN resolution on the post-2015 SDG agenda amounts to a non-binding policy document with questionable governance mechanisms that do not adequately reference "human rights" (or even, "rights") in the SDG metrics framework (which will become, in light of MDG experience, the implementation action plan for "people, planet and prosperity" for the next 15 years), then concern the human rights of persons with disabilities will likely be sidelined from SDG implementation is well-founded. This concern is furthered by the SDG metrics' insufficient identification and inclusion of persons with disabilities (along with other vulnerable population's alluded to in paragraph 23 of the UN resolution on the post-2015 SDG agenda). While persons with disabilities are identified in the achievement of three post-2015 goals (see Table 2), if the rights of persons with disabilities are to be mainstreamed in development per the CRPD's preamble then persons with disabilities must be identified and named in the achievement of each and every SDG-not only three.

To summarise, if persons with disabilities are not affirmatively named in SDG metrics then, as with human rights omission from such metrics, it is unlikely governments will pro-actively identify and adequately include persons with disabilities in implementing their SDG targets and plans of action. Subsequently there is a real risk persons with disabilities will fall between the SDG cracks. Certainly, if MDG experience is anything to go by [56,57], if persons with disabilities are not named in the metrics of all 17 SDGs, it is highly unlikely affirmative action will be taken by UN Member States to specifically redress the development inequities, abuses and complex human rights breaches persons with disabilities unconscionably, and all too-often, silently suffer in low-, middle-, and high-income nations around the world. 


\section{Conclusions}

Persons with disabilities and their advocates should not be deceived by the post-2015 SDG's appearance as a major accomplishment for advancing both human rights and the human rights of persons with disabilities, everywhere, in global development policy and planning efforts. Although the SDGs appear to be an advance for human rights and persons with disabilities, especially in contrast to parallel omission of both human rights and persons with disabilities from the MDG agenda, this "double coup" might transpire to be little more than subterfuge. This is because, as this article contends, a worrying disjunct exists between human rights' treatment in the one post-2015 SDG text agreed upon by the UN General Assembly. It follows the UN General Assembly's emphasis on human rights and the prioritisation of the development needs and issues of persons with disabilities in the preamble and content of the declaration of the UN resolution on the post-2015 SDG agenda is in keeping with the CRPD and enormously promising. Yet conversely, the marginalisation of human rights as well as persons with disabilities in the SDG metrics framework found within that same- unenforceable-UN policy document, creates intense unease. Based on over ten years of MDG experience this unease is well-founded: it is highly unlikely UN Member States will seek to extend their implementation of the UN resolution on the post-2015 SDG agenda beyond the parameters of its SDG metrics framework-from which human rights and persons with disabilities are sidelined.

Somewhat paradoxically, the UN resolution on the post-2015 SDG agenda reveals that as at September 2015, the UN General Assembly has not agreed on the location of, or overlap between, human rights and development in the post-MDG world. Thus it can be reasonably anticipated MDG antagonism and discord between rights and development will continue in UN Member State's implementation of the SDG program. Therefore, for persons with disabilities in particular, the UN resolution on the post-2015 SDG agenda might not be "the bold and transformative" development plan that it initially appears on paper. Rather, this article identifies a real risk exists that persons with disabilities, and other vulnerable populations, will be left behind in global post-2015 SDG planning and implementation efforts. Arguably, the post-2015 SDG action agenda might be inherently flawed.

Persons with disabilities and disability rights advocates must remain vigilant as the post-2015 SDG agenda moves into 2016 and beyond. Including, or better still mainstreaming, persons with disabilities in country-specific SDG targets and indicators is an excellent starting point. Ensuring that those same targets and indicators are integrated into all government SDG-related policy and planning efforts is the next step. Generating in-country, community awareness as to UN Member State's responsibilities under both the CRPD and the UN resolution on the post-2015 SDG agenda in progressing disability-inclusive development, and holding UN Member State's accountable, will be crucial. Disability advocates must also not forget to include vulnerable non-nationals with disabilities in post-2015 advocacy efforts, such as those individuals with disabilities fleeing persecution or caught in complex, irregular migration contexts. Tracing UN Member State's incorporation of persons with disabilities in their post-2015 SDG development policy and planning efforts outside State borders is of equal import, especially in relation to progressing Article 32 CRPD achievement.

Clearly, persons with disabilities and their advocates have much to monitor in the unfolding post-2015 SDG landscape. If such persons and advocates are dissatisfied that UN Member States (and their partner's) burgeoning implementation of the post-2015 SDGs lacks adequate focus on persons with disabilities, then further action must be taken. If this is the case (and I think it likely), then it is recommended that persons with disabilities, disability advocates and their supporters together press individual countries, SDG regional monitoring bodies, the recently devised High-Level Political Forum on Sustainable Development [49], as well as the UN General Assembly for a new goal and/or cluster of new disability-inclusive targets to be inserted into the SDG list. This new goal and/or cluster of targets (or indicators) must be explicitly linked to Article 32 of the CRPD, as well as the CRPD's broader content. It is also advisable that advocacy on this front begins now and not later. It is instructive that there is precedent for such action: sexual and reproductive health and rights advocates were successful in expanding MDG 5: Improve Maternal Health to include Target 5B (Achieve, by 2015, universal access 
to reproductive health) some years after the MDGs were devised [58], while Afghanistan and other nations introduced a country-relevant MDG 9 [59].

In addition to pressing for international, regional, and national accountability and monitoring mechanisms for the specific implementation of the SDG agenda for persons with disabilities, I further recommend that advocates call for a fourth and critical level of SDG monitoring [60]. Here, I recommend persons with disabilities and their advocates establish a specialist international disabilities and SDG commission (or peak body of similar nature), which could work with communities, countries, as well as other regional and international SDG monitoring agencies, to streamline and link Member States' SDG metrics reporting to their international reporting obligations under the CRPD [60]. In this way, the accountability concerns relating to the soft law nature of the post-2015 SDG outcome document might have greater chance of being remedied. This in turn leads to my final point: disability advocates must also press that implementation of the SDGs, and the parallel progression of the rights of persons with disabilities around the globe, is not "all about the metrics", or the numbers and the quantitative. Indeed, reducing disability-inclusive development to "the numbers" places the people at the heart of such development efforts—the person with disabilities—secondary to an all-consuming focus by government on quantitative measurement. This secondary positioning is arguably an insidious and repackaged form of the biomedical model approach toward disability creeping into the human development policy and planning efforts of the CRPD States Parties. This is not only morally unacceptable; it is unlawful pursuant the terms of the CRPD. Therefore, within efforts to measure SDG achievement for persons with disabilities, the qualitative must also be captured, or the voices and the experiences of SDG development on persons with disabilities and their supporters.

Acknowledgments: The funding for Go4Health, a research project of which this analysis was part, was provided by the European Union's Seventh Framework Programme (grant HEALTH-F1-2012-305240) and by the Australian Government's NH \& MRC-European Union Collaborative Research Grants (grant 1055138). The views expressed in this article are the author's alone. The author thanks the two peer-reviewer's for their guidance and Peter Hill, School of Public Health, The University of Queensland, for feedback on the final manuscript.

Conflicts of Interest: The author declares no conflict of interest.

\section{Abbreviations}

The following abbreviations are used in this manuscript:

CRPD Convention on the Rights of Persons with Disabilities

MDG Millennium Development Goal

NGOs Non-government organisations

SDG Sustainable Development Goal

UN United Nations

UNDG UN Development Group

\section{References}

1. UN General Assembly. “Transforming our World: The 2030 Agenda for Sustainable Development.” 2015. Available online: http:/ / www.un.org/ga/search/view_doc.asp?symbol=A/RES/70/1\&Lang=E (accessed on 29 March 2016).

2. UN General Assembly. "Road Map towards the Implementation of the UN Millennium Declaration: Report of the Secretary-General." 6 September 2001. Available online: http://www.un.org/documents/ga/docs/ 56/a56326.pdf (accessed on 29 March 2016).

3. Ooms, Gorik, Claire Brolan, Natalie Eggermont, Asbjørn Eide, Walter Flores, Lisa Forman, Eric A. Friedman, Thomas Gebauer, Lawrence O. Gostin, and Peter S. Hill, et al. “Universal health coverage anchored in the right to health." Bulletin of the World Health Organization 91 (2013): 2. [CrossRef] [PubMed]

4. Hill, Peter S., Kent Buse, Claire E. Brolan, and Gorik Ooms. "How can health remain central post-2015 in a sustainable development paradigm?" Globalization and Health 10 (2014): 18. [CrossRef] [PubMed] 
5. Brolan, Claire E., and Peter S. Hill. "Countdown for health to the post-2015 UN Sustainable Development Goals." Medical Journal of Australia 202 (2015): 289-90. [CrossRef] [PubMed]

6. Mulumba, Moses, Juliana Nantaba, Claire E. Brolan, Ana Lorena Ruano, Katie Brooker, and Rachel Hammonds. "Perceptions and experiences of access to public healthcare by people with disabilities and older people in Uganda." International Journal for Equity in Health 13 (2014): 76. [CrossRef] [PubMed]

7. Durham, Jo, Claire E. Brolan, and Bryan Mukandi. "The Convention on the Rights of Persons with Disabilities: A foundation for ethical disability and health research in developing countries." American Journal of Public Health 104 (2014): 2037-43. [CrossRef] [PubMed]

8. Ngo, Anh D., Claire Brolan, Lisa Fitzgerald, Van Pham, and Ha Phan. “Voices from Vietnam: Experiences of children and youth with disabilities, and their families, from an Agent Orange affected rural region." Disability and Society 28 (2012): 955-69. [CrossRef]

9. Brolan, Claire E., K. Van Dooren, M. Taylor Gomez, Robert S. Ware, and Nicholas G. Lennox. "Suranho healing: Filipino concepts of intellectual disability and treatment choices in Negros Occidental." Disability and Society 29 (2013): 71-85. [CrossRef]

10. Brolan, Claire E., M. Taylor Gomez, Nicholas G. Lennox, and Robert S. Ware. "Australians from a non-English speaking background with intellectual disability: The importance of research." Journal of Intellectual and Developmental Disability 38 (2013): 70-73. [CrossRef] [PubMed]

11. UN General Assembly. "Resolution adopted by the General Assembly. United Nations Millennium Declaration." 18 September 2000. Available online: http://www.un.org/millennium/declaration/ares552e. pdf (accessed on 29 March 2016).

12. United Nations. "Convention on the Rights of Persons with Disabilities. Adopted 13 December 2016, GA Res 61/106, UN Doc A/Res/61/106, Entered into Force 3 May 2008.” Available online: http:/ /www.un.org/ disabilities/convention/conventionfull.shtml (accessed on 29 March 2016).

13. Harpur, Paul. "Embracing the new disability rights paradigm: The importance of the Convention on the Rights of Persons with Disabilities." Disability and Society 27 (2012): 1-14. [CrossRef]

14. Mercer, Stewart W., and Rhona MacDonald. "Disability and human rights." The Lancet 370 (2007): 548-49. [CrossRef]

15. Bhat, Neha. "Mainstreaming Disability in International Development: A Review of Article 32 on International Co-Operation on the Convention on the Rights of Persons with Disabilities." 6 May 2013. Available online: http:/ / dx.doi.org/10.2139/ssrn.2262946 (accessed on 29 March 2016).

16. Officer, Alana, and Nora E. Groce. "Key concepts in disability." The Lancet 374 (2009): 1795-96. [CrossRef]

17. Kett, Maria, and Mark van Ommeren. “Disability, conflict, and emergencies.” The Lancet 374 (2009): 1801-2. [CrossRef]

18. World Health Organization, and the World Bank. “World Report on Disability." 2011. Available online: http://www.who.int/disabilities/world_report/2011/en/ (accessed on 29 March 2016).

19. World Health Organization. "Disability and Health (Factsheet No. 352)." December 2015. Available online: http:/ / www.who.int/mediacentre/factsheets/fs352/en/ (accessed on 29 March 2016).

20. UN Development Group (UNDG). “Developing the Post-2015 Development Agenda: Opportunities at the National and Local Levels." 2014. Available online: http://www.undp.org/content/dam/undp/library/ MDG/Post2015-SDG/UNDP-MDG-Delivering-Post-2015-Report-2014.pdf (accessed on 29 March 2016).

21. Beyond2015. “UN Thematic Consultations." 2015. Available online: http://www.beyond2015.org/unthematic-consultations (accessed on 29 March 2016).

22. International Disability Alliance, and the International Disability and Development Consortium. "Include Persons with Disabilities in the Sustainable Development Process." Available online: http:/ /iddcconsortium. net/sites/default/files/pages/files/ida_and_iddc_owg_statement.pdf (accessed on 29 March 2016).

23. World Health Organization. "UN High-Level Meeting on Disability and Development." 2016. Available online: http:/ / www.who.int/disabilities/hlm/en/ (accessed on 29 March 2016).

24. UN General Assembly. “Outcome Document of the High-Level Meeting of the General Assembly on the Realization of the Millennium Development Goals and Other Internationally Agreed Development Goals for Persons with Disabilities: The Way Forward, a Disability-Inclusive Development Agenda towards 2015 and Beyond." September 2013. Available online: http://www.un.org/ga/search/view_doc.asp?symbol=A/68/L.1 (accessed on 29 March 2016). 
25. Groce, Nora E., and Jean-Francois Trani. "Millennium Development Goals and people with disabilities." The Lancet 374 (2009): 1800-1. [CrossRef]

26. Vandemoortele, Jan. "Making sense of the MDGs." Development 51 (2008): 220-27. [CrossRef]

27. Doyle, Michael W. "Dialectics of a global constitution: The struggle over the UN Charter." European Journal of International Relations 18 (2011): 601-24. [CrossRef]

28. Darrow, Mac. “The Millennium Development Goals: Milestones or Millstones? Human Rights Priorities for the Post-2015 Development Agenda." Yale Human Rights and Development Law Journal 15 (2012): 55-127.

29. Langford, Malcolm. "The Art of the Impossible: Measurement Choices and the Post-2015 Development Agenda (Background Paper Governance and Human Rights: Criteria and Measurement Proposals for a Post-2015 Development Agenda)." 2012. Available online: https://sustainabledevelopment.un.org/content/ documents /776langford.pdf (accessed on 29 March 2016).

30. Vandemoortele, Jan. "The MDG Conundrum: Meeting the Targets without Missing the Point." Development Policy Review 27 (2009): 355-71. [CrossRef]

31. McArthur, John. "Own the Goals: What the Millennium Development Goals Have Accomplished." Brookings. 21 February 2013. Available online: http://www.brookings.edu/research/articles/2013/02/21-millenniumdev-goals-mcarthur (accessed on 29 March 2016).

32. Vandemoortele, Jan. "If not the Millennium Development Goals, then What? " Third World Quarterly 32 (2011): 9-25. [CrossRef]

33. Hulme, David. "Governing global Poverty? Global ambivalence and the Millennium Development Goals." In Governance, Poverty and Inequality. Edited by Jennifer Clapp and Rorden Wilkinson. London and New York: Routledge, 2010.

34. Fukuda-Parr, Sakiko. "Recapturing the narrative of international development." In The Millennium Development Goals and Beyond. Edited by Rorden Wilkinson and David Hulme. Milton Park: Routledge, 2012.

35. Brolan, Claire E., Robert S. Ware, Miriam Taylro Gomez, and Nicholas G. Lennox. "The right to health of Australians with intellectual disability." Australian Journal of Human Rights 17 (2011): 1-32.

36. Brolan, Claire E., Sameera Hussain, Eric A. Friedman, Ana Lorena Ruano, Moses Mulumba, Itai Rusike, Claudia Beiersmann, and Peter S. Hill. "Community participation in formulating the post-2015 health and development goal agenda: Reflections on a multi-country research collaboration." International Journal for Equity in Health 13 (2014): 66. [CrossRef] [PubMed]

37. United Nations. “The Millennium Development Goals Report 2015.” Available online: http://www.un.org/ millenniumgoals/2015_MDG_Report/pdf/MDG\%202015\%20rev\%20\%28July\%201\%29.pdf (accessed on 29 March 2016).

38. Chandran, Rahul, Hannah Cooper, and Alexandra Ivanovic. "Managing Major Risks to Sustainable Development: Conflict, Disaster, the SDGs and the United Nations: A Report Prepared for the United Nations Department of Economic and Social Affairs for the 2016 Quadrennial Comprehensive Policy Review." 17 December 2015. Available online: http://www.un.org/en/ecosoc/qcpr/pdf/sgr2016-deskreviewtransition.pdf (accessed on 29 March 2016).

39. UNDP. "Helen Clark: Speech on 2030 Agenda and the SDGs in Fragile States." 3 March 2016. Available online: http:/ /www.undp.org/content/undp/en/home/presscenter/speeches/2016/03/03/helen-clark2030-agenda-and-the-sdgs-in-fragile-states-european-parliament.html (accessed on 29 March 2016).

40. Sumner, Andy. “The New Bottom Billion: What if Most of the World's Poor Live in Middle-Income Countries? Center for Global Development (CGD Brief)." March 2011. Available online: http:/ /www.cgdev.org/files/ 1424922_file_Sumner_brief_MIC_poor_FINAL.pdf (accessed on 29 March 2016).

41. Lucas, Paul, Norichika Kanie, and Nina Weitz. "Translating the SDGs to High-Income Countries: Integration at Last? IISD Reporting Services." 17 March 2016. Available online: http://sd.iisd.org/guest-articles/ translating-the-sdgs-to-high-income-countries-integration-at-last/ (accessed on 29 March 2016).

42. United Nations. "Vienna Declaration and Programme of Action: Adopted by the World Conference on Human Rights on 25 June 1993, UN Doc A/CONF.157/23." Available online: http:/ /www.un-documents. net/ac157-23.htm (accessed on 29 March 2016).

43. United Nations. "Vienna Convention on the Law of Treaties Concluded at Vienna on 23 May 1969. Entered into Force on 27 January 1980." Available online: https://treaties.un.org/doc/Publication/UNTS/Volume\% 201155/volume-1155-I-18232-English.pdf (accessed on 29 March 2016). 
44. International Court of Justice. "Statute of the International Court of Justice (Annexed to the Charter of the United Nations)." Available online: http://www.icj-cij.org/documents/?p1=4\&p2=2\#CHAPTER_II (accessed on 29 March 2016).

45. Da Rocha Ferreira, Andre, Cristieli Carvalho, Fernanda Graeff Machry, and Pedro Barreto Vianna Rigon. "Formation and Evidence of Customary International Law." UFRGS Model United Nations Journal 1 (2013): 182-201.

46. International Law Association. London Statement of Principles Relating to the Formation of General Customary International Law. London: International Law Association, 2000.

47. Shaw, Malcolm N. International Law, 4th ed. Cambridge: University of Cambridge Press, 1997.

48. Brolan, Claire E., Peter S. Hill, and Gorik Ooms. "'Everywhere but not specifically somewhere': A qualitative study on why the right to health is not explicit in the post-2015 negotiations." BMC International Health and Human Rights 15 (2015): 22. [CrossRef] [PubMed]

49. UN Sustainable Development Knowledge Platform. "High-Level Political Forum on Sustainable Development." Available online: https:/ / sustainabledevelopment.un.org/hlpf (accessed on 11 May 2016).

50. United Nations. "Millennium Goal 8 the Global Partnership for Development: Making Rhetoric a Reality." Available online: http://www.who.int/medicines/mdg/mdg8report2012_en.pdf?ua=1 (accessed on 29 March 2016).

51. Kenny, Charles, and Sarah Dykstra. "The Global Partnership for Development: A Review of MDG 8 and Proposals for the Post-2015 Development Agenda (Background Research Paper)." Submitted to the High Level Panel on the Post-2015 Development Agenda. May 2013. Available online: http://www. post2015hlp.org/wp-content/uploads/2013/05/Kenny-Dykstra_The-Global-Partnership-for-DevelopmentProposals-for-the-Post-2015-Development-Agenda.pdf (accessed on 29 March 2016).

52. Caliari, Aldo. "Analysis of Millennium Development Goal 8: A Global Partnership for Development." Journal of Human Development and Capabilities 15 (2014): 275-87. [CrossRef]

53. Fukuda-Parr, Sakiko. "Millennium Development Goal 8: Indicators for International Human Rights Obligations? " Human Rights Quarterly 28 (2006): 966-97. [CrossRef]

54. Alston, Philip. "Ships Passing in the Night: The Current State of the Human Rights and Development Debate seen through the Lens of the Millennium Development Goals." Human Rights Quarterly 27 (2005): 755-829. [CrossRef]

55. Unterhalter, Elaine. "Measuring Education for the Millennium Development Goals: Reflections on Targets, Indicators, and a Post-2015 Framework." Journal of Human Development and Capabilities 15 (2014): 176-87. [CrossRef]

56. Brolan, Claire E., Peter S. Hill, and Ignacio Correa-Velez. “Refugees: The Millennium Development Goals' Overlooked Priority Group." Journal of Immigrant and Refugee Studies 10 (2012): 426-30. [CrossRef]

57. Brolan, Claire E., Stephanie Dagron, Lisa Forman, Rachel Hammonds, Lyla Latif Abdul, and Attiya Waris. "Health rights in the post-2015 development agenda: Including non-nations." Bulletin of the World Health Organization 91 (2013): 719. [CrossRef] [PubMed]

58. UNICEF. “Expanding Millennium Development Goal 5: Universal Access to Reproductive Health by 2015." Available online: http:/ / www.unicef.org/sowc09/docs/SOWC09-Panel-1.4-EN.pdf (accessed on 29 March 2016).

59. Islamic Republic of Afghanistan (Ministry of Economy). "Afghanistan Millennium Development Goals Report 2012." Available online: http:/ /www.af.undp.org/content/dam/afghanistan/docs/MDGs/ Afghanistan\%20MDGs\%202012\%20Report.pdf (accessed on 29 March 2016).

60. De la Mothe, Eve, Jessica Espey, and Guido Schmidt-Traub. “GSDR 2015 Brief. Measuring Progress on the SDGs: Multi-level Reporting." Available online: https://sustainabledevelopment.un.org/ content/documents /6464102-Measuring\%20Progress $\% 20$ on $\% 20$ the $\% 20$ SDGs $\% 20 \% 20 \% 20 \mathrm{Multi}$-level $\%$ 20Reporting.pdf (accessed on 30 April 2016).

(C) 2016 by the author; licensee MDPI, Basel, Switzerland. This article is an open access article distributed under the terms and conditions of the Creative Commons Attribution (CC-BY) license (http://creativecommons.org/licenses/by/4.0/). 